\title{
Lymphoid proliferations in the orbit: malignant or benign?
}

\author{
R.v.d. GAAG, ' L. KOORNNEEF, ${ }^{2}$ P. van HEERDE,${ }^{3}$ Th.M. VROOM,${ }^{4}$ \\ J. H. PEGELS ${ }^{5}$ C. A. FELTKAMP ${ }^{6}$ H. J. F. PEETERS,${ }^{2}$ J. P. A. GILlisSEN, ${ }^{2}$ \\ G. M. BLEEKER, ${ }^{12}$ AND T. E. W. FELTKAMP'
}

From the 'Department of Ophthalmo-Immunology, Netherlands Ophthalmic Research Institute; ${ }^{2}$ the Orbital Centre, Academisch Medisch Centrum; ${ }^{3}$ the Department of Pathology, The Netherlands Cancer Institute; ${ }^{4}$ the Department of Pathology, the Slotervaart Hospital; ${ }^{5}$ the Department of Haematology, Academisch Medisch Centrum; and ${ }^{6}$ the Department of Electron Microscopy, The Netherlands Cancer Institute, Amsterdam

SUMmary Clinical, pathological, and immunological analysis of 20 patients with ocular adnexal lymphoid disease has demonstrated several parameters which are useful for distinguishing malignant from benign lesions. Patients in the fourth or fifth decade of life presenting with an acute history of pain, oedema, epiphora, double vision, and ptosis, with a mass localised in the lacrimal gland area, are more likely to have a pseudolymphoma or a chronic inflammatory lesion than a true non-Hodgkin lymphoma (NHL). It is not possible to obtain a definite diagnosis without surgical intervention, because only three out of nine patients with orbital NHL had evidence of a monoclonal B cell population in peripheral blood on admission to the Orbital Centre. Furthermore it was confirmed that the identification of the various orbital lymphoid infiltrates becomes more distinct when immunological techniques are added to the clinical and histopathological methods of investigation. Multidisciplinary cooperation leads to further improvement of diagnosis and treatment of ocular adnexal lymphoproliferative disease.

Lymphoid proliferations of the ocular adnexa present a challenging problem for both the ophthalmologist and the pathologist. The lymphoid proliferations are reported to comprise 10 to $15 \%$ of all space filling lesions of the orbit. ${ }^{1-3}$ Histologically these extranodal lymphoid proliferations can be classified into malignant non-Hodgkin lymphomas (NHL), benign pseudolymphomas, and chronic inflammatory lesions. ${ }^{45}$ Lesions which occupy either end of the histopathological spectrum, that is, either an obvious benign chronic inflammatory process or a malignant NHL, present few problems for the pathologist. However, not infrequently lymphoid proliferations lie between these two extremes morphologically, and the diagnosis is often a source of error ${ }^{6-9}$ Not only is the histopathological diagnosis of such a lesion difficult, but the pathogenesis, the natural history, and the relationships with systemic lymphoprolifera-

Correspondence to Dr R.v.d. Gaag, Department of OphthalmoImmunology, The Netherlands Ophthalmic Research Institute, PO Box 12141, 1100 AC Amsterdam, The Netherlands. tive diseases are poorly understood. Furthermore if classification of the tumour were possible without the use of surgical intervention to obtain biopsy tissue the patients with a pseudolymphoma or a chronic inflammatory lesion, amenable to drug treatment alone, would greatly benefit from prompter instigation of treatment. The wish to find a non-invasive method for the diagnosis of orbital space filling lesions prompted us to set up this multidisciplinary investigation of patients presenting at the Orbital Clinic over a period of three years. Cytological, histological, immunohistological, and electronmicroscopical studies of biopsy material were performed in conjunction with ophthalmological examination and immunological and haematological examination of blood and bone marrow.

\section{Patients and methods}

Twenty consecutive patients with an orbital tumour of lymphoid origin, referred to the Orbital Clinic 
over the last three years, were incorporated in this study. At presentation the age, sex, the affected eye, initial symptoms, visual acuity, motility, Hertel values, and the referral diagnosis, together with the general medical history were filed. CT scans were made on all patients in axial and/or coronal planes. In all patients an open biopsy was performed. In 18 patients with deep orbital lesions an orbitotomy was done. The lesions of 10 of these patients were approached via an anterior route. In the others a lateral orbitotomy was performed. The freshly obtained biopsy specimens were subdivided ${ }^{10}$ for routine histology, cytology, electron microscopy, immunohistochemistry, and immunological investigation of cells in suspension. Before surgery and treatment a heparinised venous blood sample was taken and a bone marrow aspirate was obtained.

\section{HISTOLOGY AND CYTOLOGY}

Histological diagnoses were made on tissue sections supplemented with imprint smears. Tissue specimens were fixed in buffered formalin and embedded in Paraplast and/or plastic when indicated. Routinely, haematoxylin and eosin, periodic acid-Schiff (PAS), methyl-green-pyronin, Giemsa, and reticulin stains were made. Imprints were stained with MayGrünwald-Giemsa. Imprints were of great use in determining the cell type of NHL especially when the biopsies were small and/or mechanically damaged."

\section{ELECTRON MICROSCOPY}

Small pieces of biopsy specimens were fixed in a solution of $2 \%$ paraformaldehyde and $2.5 \%$ glutaraldehyde in $0 \cdot 1 \mathrm{M}$ cacodylate buffer, postfixed in $1 \%$ $\mathrm{OsO}_{4}$ in the same buffer, stained en bloc with $1 \%$ aqueous uranyl acetate, dehydrated in ethanol, and embedded in a mixture of Araldite and Epon 812. Thin sections, stained with lead hydroxide, were examined with a Philips EM 301 electron microscope.

DETERMINATION OF CELL SURFACE AND

CYTOPLASMIC MARKERS IN CRYOSTAT SECTIONS BY MEANS OF IMMUNOFLUORESCENCE

The tissue specimens were snap frozen and stored in liquid nitrogen. $4 \mu \mathrm{m}$ Cryostat sections were air dried and fixed in acetone for $10 \mathrm{~min}$ at $20^{\circ} \mathrm{C}$. The sections were incubated with labelled antisera directed against human lymphocytes, ${ }^{12}$ against $T$ lymphocytes, 1 against $\alpha \gamma \delta \varepsilon \mu$ heavy chains, and $x$ and $\lambda$ light chains. Double staining was applied for $\mu$ and $\delta$, and $x$ and $\lambda$, one antiserum being labelled with fluorescein isothiocyanate (FITC), the other with tetramethylrhodamine isothiocyanate (TRITC). Indirect immunofluorescence was done on the sections with monoclonal antibodies directed against HLA-DR (supernatant 0101-2007, Cappel, USA), transferrin receptor (kindly donated by van Rijn $e t$ al. ${ }^{13}$ and against monocytes (MaHuman monocyte 133020 lot 30224, BRL, USA).

PREPARATION OF CELL SUSPENSIONS AND IMMUNOFLUORESCENCE TECHNIQUE

When enough biopsy material was available cells were teased from a portion. Dead cells, granulocytes, and erythrocytes were separated from the lymphoid cells by means of density gradient centrifugation on FicollPaque (Pharmacia). Mononuclear cells from blood were isolated by means of density gradient centrifugation. All the cells for the immunofluorescence test were fixed with paraformaldehyde, to prevent aspecific binding of immunoglobulins via the Fc receptor, ${ }^{14}$ and washed twice prior to use. B cells were determined by a direct immunofluorescence test with FITC labelled antisera against human immunoglobulins and $\alpha, \gamma, \delta, \mu$, heavy chains and $x$ and $\lambda$ light chains. ${ }^{15} \mathrm{~T}$ cells were determined by either the $\mathrm{E}$ rosette test ${ }^{16}$ or OKT monoclonal antibodies. ${ }^{17}$

Statistical analysis was performed by Student's $t$ test and the $\chi^{2}$ test.

\section{Case report}

Patient No 4. This patient was chosen as a case history to illustrate how difficult and puzzling the diagnosis and management of orbital lymphoproliferative lesions can be. The patient first presented in 1975, aged 66, with a palpable mass in the right upper eyelid, a proptosis of $4 \mathrm{~mm}$, and ptosis. Visual acuity, visual fields, skull $x$-rays, and blood tests were

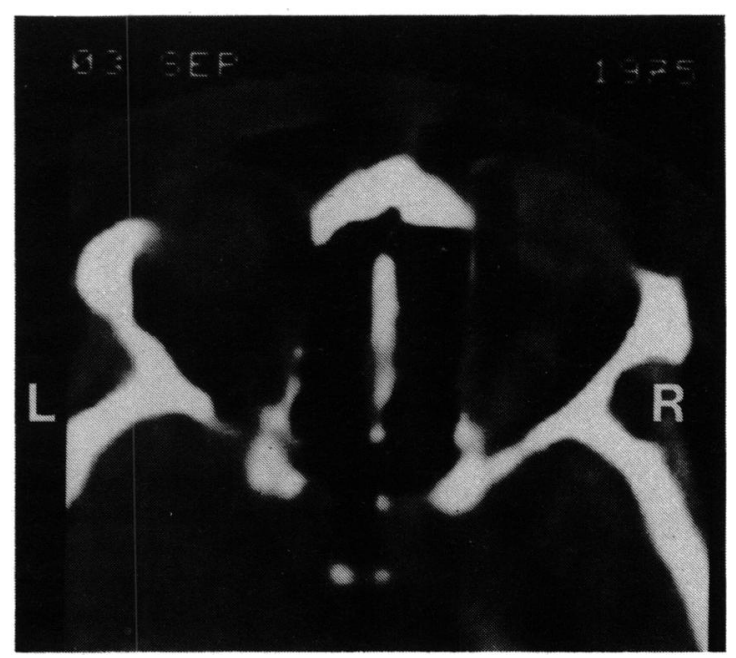

Fig. 1 CT scan appearance of patient No 4 showing a mass in the superior eyelid, lacrimal gland, and extending posteriorly. 


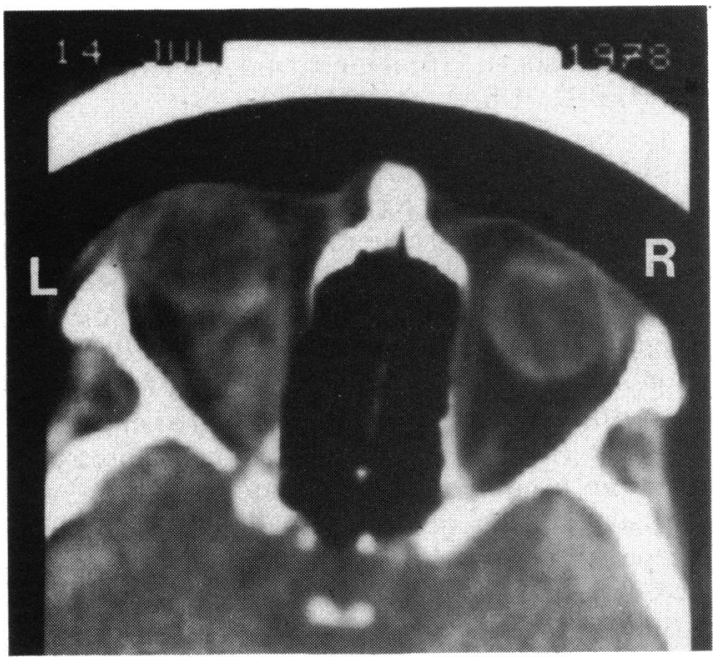

Fig. 2 CT scan image showing the mass on the orbital floor extending into the orbital apex.

normal. The CT scan (taken on 3 September 1975) (Fig. 1) showed a pathological structure in the superior eyelid extending into the right orbital apex. An anterior orbitotomy was performed, and the histopathological diagnosis was lymphocytic pseudotumour. No immunohistochemistry was done at that time. The patient was treated with a course of prednisolone and responded well. A year later the CT scan was normal. In 1978 the patient returned with a $3 \mathrm{~mm}$ proptosis in the left eye. The CT scan (Fig. 2) showed a pathological structure on the orbital floor, left, extending into the apex. After various conservative treatments without result the patient was put into this study. A biopsy was taken in 1980 and histopathology showed a diffuse centrocytic non-Hodgkin lymphoma.

Immunopathological examination of the biopsy presented a diffuse pattern of rather small tumour cells with a ring type fluorescence, positive for $\mu, x$, and HLA-DR: monoclonal B cells.

The subpopulation distribution of cells obtained from the same biopsy, studied in suspension, was as follows: $15 \%$ T cells and $37 \%$ B cells, $26 \%$ bearing $x$, $9 \% \lambda$ light chains, and $21 \% \mu$ heavy chains.

General physical examination showed no evidence for systemic disease. No enlargement of the spleen or liver was found. Serum electrophoresis revealed no abnormalities. Both cytological and immunological examination of bone marrow cells were normal.

Left orbital irradiation (4000 rads) was performed with a good result, leaving the patient in a stable condition with a follow-up of two years (Hertel 19-17 mm).

The distribution of subpopulations of lymphoid cells in peripheral blood was determined at different points in time. The patient had a marked reduction of T cells except in July 1981 (Table 1). The percentage of $B$ cells was increased at every determination, but the ratio of $x$ bearing to $\lambda$ bearing cells remained within normal limits (smaller than 4 to 1 ) until September 1982, when an abnormal B cell population, bearing $\mu, \delta, x$, was found.

\section{Results}

Twenty patients were included in this study. Table 2 summarises the clinical characteristics and the biopsy results. Eleven of these patients were female and nine male. The orbital lesions of the 20 patients were divided into three groups based on light microscopical examination of tissue sections and imprint smears. The space occupying lesion was an NHL in nine patients, characterised morphologically by a more or less monotonous cell proliferation of small and/or large lymphoid cells without normal follicular structures and with infiltrating capacity. The subdivision of the NHLs was based on the Kiel classifica-

Table 1 Lymphocyte subpopulations in peripheral blood of patient No 4

\begin{tabular}{|c|c|c|c|c|c|c|c|c|c|c|}
\hline \multirow[t]{2}{*}{ Month } & \multirow[t]{2}{*}{ Year } & \multicolumn{9}{|c|}{$\%$ Positive cells } \\
\hline & & $E r f c^{*}$ & $O K T 3$ & $B$ cell & $x$ & $\lambda$ & IgG் & $\lg M$ & $\operatorname{Ig} A$ & $\operatorname{IgD}$ \\
\hline April & 1980 & 35 & ND & 66 & 45 & 15 & 3 & 51 & 0 & 43 \\
\hline May & 1981 & 40 & ND & 27 & 16 & 9 & 1 & 25 & 1 & 25 \\
\hline July & 1981 & 55 & ND & 20 & 19 & 8 & 0 & 25 & 0 & 20 \\
\hline November & 1981 & 35 & ND & 40 & 27 & 7 & ND & ND & ND & ND \\
\hline \multirow{3}{*}{$\begin{array}{l}\text { September } \\
\text { Normal values } \dagger\end{array}$} & 1982 & ND & 41 & 33 & 27 & 4 & 1 & 19 & 0 & 11 \\
\hline & Mcan & $73 \cdot()$ & $60 \cdot()$ & $7 \cdot 5$ & $5 \cdot()$ & $3 \cdot 0$ & 0.5 & $5 \cdot 5$ & 0.5 & $5 \cdot 5$ \\
\hline & SD & $9 \cdot 5$ & $5 \cdot 0$ & $2 \cdot 5$ & $2 \cdot 5$ & $1 \cdot 5$ & 0.7 & $2 \cdot 2$ & $0 \cdot 7$ & $2 \cdot 6$ \\
\hline
\end{tabular}

*Sheep erythrocyte rosette forming cell.

† Mean of 13 healthy blood donors.

$\mathrm{ND}=$ not done. 
tion. ${ }^{18}$ Seven patients were found to have a pseudolymphoma and four a chronic inflammatory lesion. Morphologically these two groups are characterised respectively, by a comparatively monomorphous, hypercellular, reactive lymphoid hyperplasia, or by a heterogenous cell population with small and some large lymphocytes, plasma cells, eosinophils and histiocytes, by lymphfollicles with germinal centres, and by fibrosis.

The mean age of the patients in the different groups was: 66 years for patients with NHL (range 51-76), 62 years for patients with pseudolymphoma (range 51-73), and 40 years for patients with a chronic inflammatory process. The age difference between patients with NHL and with pseudolymphoma was not statistically significant $(p>0 \cdot 2)$, but the patients with a chronic inflammatory process were significantly younger than either the NHL group $(p<0.005)$ or the pseudolymphoma group $(\mathrm{p}<0.02)$.

At presentation 16 patients had a unilateral and two a bilateral orbital process. Two had a bilateral conjunctival involvement. There was a marked preponderance for the right orbit in the patients with unilateral complaints: 14 right versus 2 left sided. The symptoms at presentation were as follows: proptosis (13 patients), pain (12 patients), diplopia (11 patients), chemosis (5 patients), decrease of visual acuity (4 patients), epiphora (4 patients), ptosis (4 patients), and lid oedema (2 patients). Several patients had more than one initial complaint.

In the patients with NHL the initial complaints such as pain, proptosis, and chemosis were less acute than in the other two groups, and the duration of the complaints was very much longer (months for NHL versus weeks for pseudolymphoma and chronic inflammation). The degree of proptosis was also less marked in the patients with NHL $(2.4 \mathrm{~mm})$ than in those with either pseudolymphoma or chronic inflammation (mean $4.6 \mathrm{~mm}$ ). The CT scan showed that an NHL could be located anywhere within the orbit, whereas pseudolymphoma and chronic inflammation had a predilection for the lacrimal gland area.

All but one patient, who refused treatment, of the NHL group were treated with irradiation (4000 rads). Six patients with a pseudolymphoma were treated with a course of corticosteroids $(60 \mathrm{mg} /$ day for 14 days and then tapered off). The criteria used to define clinical improvement were established as follows: reduction of proptosis (mean improvement NHL $2 \mathrm{~mm}$, the pseudolymphoma and chronic inflammation patients, $4 \mathrm{~mm}$ ); improved ocular motility and increased visual acuity (unchanged or improved in all patients). The results of treatment were satisfactory for all the patients (Table 2).
Immunohistochemical analysis was performed on 19 out of 20 biopsies (Table 3). Six of the patients studied showed a definite monoclonal B cell population all characterised by IgM and HLA-DR. Three bore $x$ light chains, three others $\lambda$ chains, and one lymphoma was also IgD positive. In two patients a discrepancy between the results of the histological and the immunohistochemical examination was present. Patient No 8 was diagnosed as having a diffuse centrocytic lymphoma, but no monoclonality of B cells was found. The biopsy taken from patient No 1 was negative for immunoglobulin chains but definitively positive for HLA-DR, and the monocyte antibody, and was therefore diagnosed immunohistochemically as a true histiocytic lymphoma but histologically as a diffuse centroblastic NHL. In these two cases the sections were reassessed, but both the light microscopical and immunohistochemical diagnosis remained unchanged, and consequently patient No 8 was treated for NHL. Patient No 1 refused treatment.

The density of the transferrin receptor on the cell membrane is a marker for proliferative activity of lymphoid cells. ${ }^{19}$ It has also been shown that there is a correlation between the density distribution of transferrin receptors on tumour cells and the degree of malignancy. ${ }^{21} \mathrm{We}$ looked for the presence or absence of the transferrin receptor on biopsy material from patients 1 to 7 using a monoclonal mouse antitransferrin receptor antibody $(661 \mathrm{G10})$. The results show that out of the seven tumours investigated only two (Nos 1 and 2) had a moderately dense distribution of transferrin receptors. In the case of patient No 1 this might not have a predictive value, as monocytes always have transferrin receptors. But, on the other hand, if this patient had a diffuse centroblastic NHL as diagnosed morphologically, this tumour would be of high grade malignancy. Patient follow-up will have to show whether these findings in this patient and the other six patients have any significance regarding the prognostic value. Immunohistochemistry of the 11 other biopsies showed a $T$ cell and polyclonal B cell infiltrate with a predominance of $T$ cells over the $B$ cells. In one of the pseudolymphoma patients a slight predominance of $\operatorname{IgM} / \varkappa$ plasma cells was observed. Follow-up of this patient is necessary in order to evaluate whether this pseudolymphoma will evolve into a monoclonal B cell lymphoma.

Cell suspensions teased from six biopsies were investigated for lymphocyte subpopulations (Table 3 ). In three biopsies, classified morphologically as NHL, the $x$ bearing cells outnumbered the $\lambda$ bearing cells, but the ratio never exceeded 3.5 to 1 . In patient No 8 , described morphologically as having a diffuse centrocytic NHL but immunohistochemically as polyclonal, the number of $T$ cells was greater than in the other 
Table 2 Clinical, radiological, and histopathological findings. Treatment and course of disease

\begin{tabular}{|c|c|c|c|c|c|c|}
\hline Case & Age/sex/date & Eye(s) & Initial complaints & Medical history & Location on CT-scan & Surgical approach \\
\hline 1 & $\begin{array}{l}64 / F \\
22 \text { Dec } 1981\end{array}$ & OD & $\begin{array}{l}\text { Pain, epiphora, } \\
\text { double vision }\end{array}$ & None & Inferior/medial & Anterior orbitotomy \\
\hline 2 & $\begin{array}{l}71 / M \\
22 \text { Dec } 1981\end{array}$ & OD & $\begin{array}{l}\text { Double vision, pain, } \\
\text { proptosis, chemosis }\end{array}$ & None & Retrobulbar & Lateral orbitotomy \\
\hline 3 & $\begin{array}{l}51 / M \\
13 \text { Jan } 1981\end{array}$ & OD/OS & Ptosis, vision $\downarrow$ & $\begin{array}{l}79 \text { Brill } \\
\text { Symmers disease }\end{array}$ & $\begin{array}{l}\text { Superior eyelid, } \\
\text { first OD, later OS }\end{array}$ & Anterior orbitotomy \\
\hline 4 & $\begin{array}{l}\text { 66/M } \\
3 \text { July } 1980\end{array}$ & OD/OS & $\begin{array}{l}\text { Pain, proptosis, lid } \\
\text { oedema, chemosis }\end{array}$ & $\begin{array}{l}\text { Thrombosis leg, } \\
\text { maturity onset } \\
\text { diabetes }\end{array}$ & $\begin{array}{l}\text { Superior eyelid, first } \\
\text { OD, later OS and } \\
\text { apex }\end{array}$ & Anterior orbitotomy \\
\hline 5 & $\begin{array}{l}58 / F \\
17 \text { Sept } 1981\end{array}$ & OD & $\begin{array}{l}\text { Proptosis, pain } \\
\text { ptosis }\end{array}$ & None & Temporal & Lateral orbitotomy \\
\hline 6 & $\begin{array}{l}76 / F \\
27 \text { Oct } 1982\end{array}$ & OD & $\begin{array}{l}\text { Proptosis, } \\
\text { double vision }\end{array}$ & None & $\begin{array}{l}\text { Retrobulbar } \\
\text { superior/medial }\end{array}$ & Anterior orbitotomy \\
\hline 7 & $\begin{array}{l}\text { 72/M } \\
19 \text { May } 1982\end{array}$ & OD & $\begin{array}{l}\text { Proptosis, double } \\
\text { vision, epiphora }\end{array}$ & $\begin{array}{l}\text { Stomach carcinoma } \\
1980\end{array}$ & Retrobulbar & Anterior orbitotomy \\
\hline 8 & $\begin{array}{l}\text { 62/M } \\
23 \text { Oct } 1980\end{array}$ & OD & $\begin{array}{l}\text { Proptosis, double } \\
\text { vision }\end{array}$ & $\begin{array}{l}1975 \text { kidney stone } \\
\text { operation } \\
1977 \text { cholecystectomy }\end{array}$ & Lateral + retrobulbar & Anterior orbitotomy \\
\hline 9 & $\begin{array}{l}71 / F \\
12 \text { Oct } 1981\end{array}$ & OD/OS & Chemosis & None & Conjunctival & Open biopsy anterior \\
\hline 10 & $\begin{array}{l}57 / F \\
26 \text { Nov } 1982\end{array}$ & OD/OS & Pain + chemosis & None & Conjunctival & Open biopsy anterior \\
\hline 11 & $\begin{array}{l}57 / \mathrm{M} \\
1 \text { Oct } 1981\end{array}$ & OD & Proptosis, pain & Cardial disease & Retrobulbar & Lateral orbitotomy \\
\hline 12 & $\begin{array}{l}\text { 67/F } \\
13 \text { April } 1982\end{array}$ & OD & $\begin{array}{l}\text { Diplopia, pain, } \\
\text { proptosis, ptosis }\end{array}$ & Hypertension & Retrobulbar medially & $\begin{array}{l}\text { Transconjunctival orbitotom } \\
\text { Lateral orbitotomy }\end{array}$ \\
\hline 13 & $\begin{array}{l}66 / \mathrm{M} \\
20 \text { May } 1980\end{array}$ & OD & Diplopia, proptosis & None & Lateral/superior & Anterior orbitotomy \\
\hline 14 & $\begin{array}{l}51 / F \\
4 \text { Nov } 1980\end{array}$ & OD & Pain & None & Lateral/superior & Lateral orbitotomy \\
\hline 15 & $\begin{array}{l}60 / F \\
19 \text { August } 1980\end{array}$ & OD & $\begin{array}{l}\text { Proptosis, diplopia } \\
\text { epiphora }\end{array}$ & Diabetes & Lateral/superior & Anterior orbitotomy \\
\hline 16 & $\begin{array}{l}\text { 73/M } \\
25 \text { March } 1980\end{array}$ & OS & $\begin{array}{l}\text { Proptosis, pain, } \\
\text { diplopia }\end{array}$ & Hyperthyroidism & Superior retrobulbar & Anterior orbitotomy \\
\hline 17 & $\begin{array}{l}61 / F \\
13 \text { May } 1981\end{array}$ & OS & $\begin{array}{l}\text { Pain, lid oedema } \\
\text { diplopia }\end{array}$ & None & Lateral/superior & Anterior orbitotomy \\
\hline 18 & $\begin{array}{l}45 / F \\
1 \text { June } 1981\end{array}$ & OD & Proptosis & None & $\begin{array}{l}\text { Retrobulbar } \\
\text { (enlarged muscle) }\end{array}$ & $\begin{array}{l}\text { Open biopsy } \\
\text { anterior }\end{array}$ \\
\hline 19 & $\begin{array}{l}27 / F \\
7 \text { Sept } 1981\end{array}$ & OD & $\begin{array}{l}\text { Ptosis, chemosis, } \\
\text { double vision, pain }\end{array}$ & None & Lateral retrobulbar & Lateral orbitotomy \\
\hline 20 & $\begin{array}{l}26 / \dot{M} \\
22 \text { July } 1980\end{array}$ & OD & $\begin{array}{l}\text { Pain, epiphora, } \\
\text { proptosis }\end{array}$ & None & Lateral/superior & Lateral orbitotomy \\
\hline
\end{tabular}

two cases. In the three other biopsies, classified morphologically as pseudolymphoma and by immunohistochemistry as polyclonal, the number of $T$ cells was greater or equal to $23 \%$, and the B cells were polyclonal.

Three of the NHL and two of the pseudolymphoma biopsies were screened electron microscopically (Table 3). Of special interest is the result in patient No 1 , in whom a discrepancy existed between the morphological and the immunohistochemical diag- nosis. The tissue appeared very heterogeneous. In between a mixture of fibroblasts and small lymphocytes small groups of large, pale staining cells were observed. Ultrastructurally the cells had very few organelles and a regular or lobulated nucleus that frequently showed nuclear pockets. No cell contacts were observed between these cells. Based on their ultrastructure a distinction between a lymphocytic (most likely centroblastic) or a histiocytic character could not be made. The morphology of the two other 


\begin{tabular}{|c|c|c|c|c|c|c|c|c|}
\hline \multirow[t]{2}{*}{ Biopsy results } & \multicolumn{2}{|l|}{$V A$} & \multicolumn{2}{|l|}{ Motility } & \multicolumn{2}{|c|}{ Exophthalmometer } & \multirow{2}{*}{$\begin{array}{l}\text { Follow up } \\
\text { (months) }\end{array}$} & \multirow[t]{2}{*}{ Treatment } \\
\hline & Initial & Final & Initial & Final & Initial & Final & & \\
\hline $\begin{array}{l}\text { Diffuse centroblastic } \\
\text { NHL }\end{array}$ & $20 / 20$ & $20 / 20$ & $5 \%$ Depression & $\begin{array}{l}5 \% \text { Depression } \\
20 \% \text { Adduction } \\
15 \% \text { Elevation }\end{array}$ & 13-11 & $14-13$ & 26 & Patient refused treatment \\
\hline $\begin{array}{l}\text { Diffuse lympho- } \\
\text { plasmacytoid NHL }\end{array}$ & $20 / 20$ & $20 / 20$ & $\begin{array}{l}\text { Strab conv + } \\
\text { total limit of } \\
\text { abduction }\end{array}$ & $15 \%$ Abduction & $18-17$ & $14-15$ & 8 & 4000 Rads \\
\hline $\begin{array}{l}\text { Follicular centroblastic/ } \\
\text { centrocytic NHL }\end{array}$ & $20 / 40$ & $20 / 20$ & $\begin{array}{l}90 \% \text { depression } \\
+ \text { elevation }\end{array}$ & Full & $18-18$ & $15-17$ & 24 & $\begin{array}{l}4000 \text { Rads later } \\
\text { total body irradiation }\end{array}$ \\
\hline $\begin{array}{l}\text { 1. Pseudotumour } \\
\text { 2. Diffuse centrocytic } \\
\text { NHL }\end{array}$ & $20 / 20$ & $20 / 20$ & Full & Full & $21-17$ & $19-17$ & 90 & $\begin{array}{l}\text { 1. Prednisolone } \\
\text { 2. Endoxan } \\
\text { 3. Immuran + pred } \\
\text { 4. } \mathbf{4 0 0 0} \text { Rads }\end{array}$ \\
\hline $\begin{array}{l}\text { Diffuse centrocytic } \\
\text { NHL }\end{array}$ & $20 / 20$ & $20 / 20$ & Full & Full & $19-14$ & $18-15$ & 15 & $\begin{array}{l}\text { Prednisolone no effect, } \\
\text { radiotherapy } 4000 \text { Rads }\end{array}$ \\
\hline $\begin{array}{l}\text { Diffuse centrocytic } \\
\text { NHL }\end{array}$ & $20 / 20$ & $20 / 60$ & $\begin{array}{l}80 \% \text { Elevation } \\
85 \% \text { Adduction } \\
90 \% \text { Depression }\end{array}$ & - & $22-18$ & $21-18$ & 3 & 4000 Rads \\
\hline $\begin{array}{l}\text { Diffuse centrocytic } \\
\text { NHL }\end{array}$ & $20 / 20$ & $20 / 30$ & $\begin{array}{l}20 \% \text { Elevation } \\
90 \% \text { Abduction } \\
80 \% \text { Adduction }\end{array}$ & Ptosis & $22-17$ & $19-20$ & 6 & 4000 Rads \\
\hline $\begin{array}{l}\text { Diffuse centrocytic } \\
\text { NHL }\end{array}$ & $20 / 20$ & $20 / 20$ & $\begin{array}{l}90 \% \text { Elevation } \\
90 \% \text { Depression }\end{array}$ & Full ptosis & $22-18$ & $12-13$ & 28 & 4120 Rads \\
\hline $\begin{array}{l}\text { Diffuse centrocytic } \\
\text { NHL }\end{array}$ & $20 / 30$ & $20 / 30$ & Full & Full & $16-16$ & $16-16$ & 15 & 3171 Rads \\
\hline Pseudolymphoma & $20 / 20$ & $20 / 20$ & Full & Full & $16-16$ & $16-16$ & 4 & Prednisone \\
\hline Pseudolymphoma & $20 / 20$ & $20 / 20$ & Full & Full & $28-24$ & $20-20$ & 9 & Prednisone \\
\hline Pseudolymphoma & $20 / 30$ & $20 / 30$ & Frozen globe & Frozen globe & $17-12$ & $12-14$ & 8 & Prednisone \\
\hline Pseudolymphoma & $20 / 30$ & $20 / 30$ & $\begin{array}{c}5 \% \text { Elevation } \\
50 \% \text { Abduction } \\
80 \% \text { Adduction }\end{array}$ & No follow up & $23-18$ & $18-18$ & 21 & Prednisone \\
\hline Pseudolymphoma & $20 / 20$ & $20 / 20$ & Full & Full & $22-17$ & $15-17$ & 28 & None \\
\hline Pseudolymphoma & $20 / 40$ & Unknown & $\begin{array}{l}80 \% \text { Elevation } \\
80 \% \text { Abduction }\end{array}$ & $\begin{array}{l}70 \% \text { Elevation } \\
\text { ptosis }\end{array}$ & $18-12$ & No follow up & None & None \\
\hline Pseudolymphoma & $20 / 30$ & $20 / 20$ & $5 \%$ Elevation & Full & $17-22$ & $22-23$ & 9 & Prednisone \\
\hline Chronic inflammation & $20 / 20$ & $20 / 20$ & $90 \%$ Elevation & Full & $21-21$ & $20-20$ & 18 & None \\
\hline Chronic inflammation & $20 / 20$ & $20 / 20$ & $\begin{array}{l}5 \% \text { Elevation } \\
20 \% \text { abduction } \\
\text { and adduction }\end{array}$ & No follow up & $29-20$ & No follow up & None & None \\
\hline Chronic inflammation & $20 / 30$ & $20 / 20$ & Full & Full & $19-14$ & $11-12$ & 7 & $\begin{array}{l}\text { None } \\
\text { (clamoxyl, vibramycine) }\end{array}$ \\
\hline Chronic inflammation & $20 / 30$ & $20 / 20$ & Full & Full & $19-17$ & $20-19$ & 30 & Prednisone \\
\hline
\end{tabular}

NHLs (Nos 3 and 4) was very similar. The tissues consisted of small and somewhat enlarged lymphoid cells with a regular or slightly indented nucleus with moderately condensed chromatin, a distinct Golgi apparatus, few endoplasmic reticulum profiles, and free ribosomes. Very few granules were observed. The ultrastructure resembled that of centrocytes. ${ }^{21}$ The two biopsies of the patients with a pseudolymphoma were very different in appearance. The tissue of case 13 was very heterogeneous, consisting of small lymphocytes (possibly B cells), somewhat larger lymphocytes with an indented nucleus (possibly activated T cells), immature plasma cells, histiocytes, and fibroblasts. As a whole this resembled the morphology of $T$ cell areas within lymph nodes. The tissue blocks of case 14 were all derived from a follicular area with centroblasts surrounded by a network of cellular protrusions.

In order to understand the relationship of the orbital process with systemic disease and the wish to 
Table 3 Immunohistopathological, electron microscopical, and immunological results

\begin{tabular}{|c|c|c|c|c|c|c|c|c|}
\hline \multirow{2}{*}{$\begin{array}{l}\text { Patient } \\
\text { No. }\end{array}$} & \multirow[t]{2}{*}{ Age/sex } & \multicolumn{2}{|c|}{ Clonality of lymphoid cells in the biopsy } & \multirow{2}{*}{$\begin{array}{l}\text { Electron microscopy } \\
\text { of the biopsy }\end{array}$} & \multicolumn{4}{|c|}{ Lymphocyte subpopulations in peripheral blood } \\
\hline & & $\begin{array}{l}\text { Immuno- } \\
\text { histochemistry }\end{array}$ & Cell suspension & & $\%$ T cells & $\%$ B cells & $\% x$ & $\% \lambda$ \\
\hline 1 & $64 \mathrm{~F}$ & $\begin{array}{l}\mathrm{Ia}^{+}, \text {few T } \\
\text { and B cells }\end{array}$ & ND & $\begin{array}{l}\text { Mixed population }+ \\
\text { activated T cells }\end{array}$ & 38 & 3 & 2 & 2 \\
\hline 2 & $71 \mathrm{M}$ & $\mu \lambda \mathbf{I a}^{+}$ & ND & ND & 57 & 3 & 3 & () \\
\hline $3^{*}$ & $51 \mathrm{M}$ & $\mu x \mathrm{Ia}^{+}$ & $9 \% \mathrm{~T}, 14 \% \mathrm{~B}, 10 \% x, 5 \% \lambda$ & $\begin{array}{l}\text { Homogenous } \\
\text { centrocytic population }\end{array}$ & 52 & 27 & 14 & 3 \\
\hline 4 & $66 \mathrm{M}$ & $\mu x \mathrm{Ia}^{+}$ & $12 \% \mathrm{~T}, 36 \% \mathrm{~B}, 26 \% x, 9 \% \lambda$ & $\begin{array}{l}\text { CLL type lymphoid } \\
\text { cells }\end{array}$ & \multicolumn{4}{|c|}{ Sec Table 1} \\
\hline 5 & $58 \mathrm{~F}$ & $\mu \lambda \mathrm{Ia}^{+}$ & ND & ND & 59 & 10 & 5 & 1 \\
\hline 6 & $76 \mathrm{~F}$ & $\mu \sigma x \mathrm{Ia}^{+}$ & ND & ND & 46 & ND & 45 & 1 \\
\hline 7 & $72 \mathrm{M}$ & $\mu \lambda \mathrm{Ia}^{+}$ & ND & ND & 54 & 9 & 7 & 5 \\
\hline 8 & $62 \mathrm{M}$ & Polyclonal & $49 \% \mathrm{~T}, 20 \% \mathrm{~B}, 21 \% x, 6 \% \lambda$ & ND & 64 & 18 & 13 & 7 \\
\hline 9 & $71 \mathrm{~F}$ & ND & ND & ND & 46 & 5 & 2 & 1 \\
\hline 10 & $57 \mathrm{~F}$ & Polyclonal & ND & ND & ND & ND & ND & ND \\
\hline 11 & $57 \mathrm{M}$ & $\begin{array}{l}\text { Lymphocytes } \\
\text { polyclonal } \\
\text { plasma cells } \mu x\end{array}$ & ND & ND & 58 & 3 & 3 & 1 \\
\hline 12 & $67 \mathrm{~F}$ & Polyclonal & ND & ND & 70 & 9 & 5 & 4 \\
\hline 13 & $66 \mathrm{M}$ & Polyclonal & $23 \% \mathrm{~T}, 11 \% \mathrm{~B}, 6 \% x, 7 \% \lambda$ & $\begin{array}{l}\text { Mixed population } \\
\text { lymphoid cells }\end{array}$ & 56 & 24 & 13 & 6 \\
\hline 14 & $51 \mathrm{M}$ & Polyclonal & $37 \%$ T, $36 \%$ B, $28 \% x, 12 \% \lambda$ & $\begin{array}{l}\text { Medium sized } \\
\text { centroblasts }\end{array}$ & 58 & 6 & 2 & 3 \\
\hline 15 & $60 \mathrm{~F}$ & Polyclonal & $52 \% \mathrm{~T}, 35 \% \mathrm{~B}, 20 \% x, 13 \% \lambda$ & $\cdot N D$ & 60 & 41 & 22 & 21 \\
\hline 16 & $73 \mathrm{M}$ & Polyclonal & ND & ND & 36 & 21 & 10 & 7 \\
\hline 17 & $61 \mathrm{~F}$ & Polyclonal & ND & ND & 78 & 21 & 14 & 10 \\
\hline 18 & $45 \mathrm{~F}$ & Polyclonal & ND & ND & 77 & 5 & 2 & 2 \\
\hline 19 & $27 \mathrm{~F}$ & Polyclonal & ND & ND & 68 & 19 & 9 & 5 \\
\hline 20 & $26 \mathrm{M}$ & Polyclonal & ND & ND & 76 & 12 & 3 & 4 \\
\hline \multicolumn{5}{|c|}{ Controlst } & $6 \cdot() \pm 5 \cdot() \ddagger$ & $7 \cdot 5 \pm 2 \cdot 5$ & $5 \cdot() \pm 2 \cdot 5$ & $3 \cdot 0 \pm 1 \cdot 7$ \\
\hline
\end{tabular}

${ }^{*}$ Treated with Leukeran. $\quad$ Thirteen healthy blood donors. $\quad \ddagger$ Mean \pm SD. $\quad$ ND= not done.

find an ophthalmologically non-invasive method for diagnosis immunological studies were performed on bone marrow cells and peripheral blood lymphocytes. Immunocytological investigations of bone marrow cells were carried out in 11 patients (Nos 2, 4, 6, 7, 9, $10,11,12,13,17$, and 18). In only one patient (No 6) could a monoclonal $\mathrm{B}$ cell lymphocytic population be detected. The distribution of $T$ and $B$ cells in peripheral blood was determined on the day after admission to the Orbital Centre (Table 3). Patient No 4 is reported separately as a case report. Of the other eight patients with NHL three had an abnormal distribution of $x$ versus $\lambda$ bearing $B$ cells, one had a polyclonal increase of B cells, and three had low $T$ cell levels. In the patients with pseudolymphoma or chronic inflammation no abnormalities were detected in the $x: \lambda$ ratios. A polyclonal increase of $B$ cells was seen in five patients, one patient had low T cell levels, and three patients raised $\mathrm{T}$ cell levels.

\section{Discussion}

Our results show that there was a difference in clinical presentation between patients with NHL and patients with a pseudolymphoma or a chronic inflammatory lesion. This finding contrasts with that of some other investigators. ${ }^{69}$ Patients with a recent and acute history of clinical signs like pain, oedema, epiphora, double vision, and proptosis, and of fairly young age, were more liable to have a pseudolymphoma or chronic inflammation than patients of more advanced age with a longer history of complaints. These results concur with those of Garner et al., ${ }^{9}$ when their final diagnosis table is integrated in the table of clinical and radiological findings. The localisation of the tumour inside the orbit ${ }^{22}$ on the CT $\operatorname{scan}^{23}$ also gave a fairly accurate diagnosis as to its type. A marked preference for the lacrimal gland area was seen in patients with either a pseudolymphoma or chronic inflammation. This observation was clearly illustrated by our case report. This patient first presented with a pseudolymphoma in the lacrimal gland area of the right orbit and later with a retrobulbar NHL of the left orbit. There appeared to be little tendency to dissemination in the NHL patients. In one patient generalised disease was manifest before the orbital 
complaints. In one other patient monoclonal B cells were found in the bone marrow aspirate. The distribution of $x$ versus $\lambda$ bearing $B$ cells in peripheral blood was abnormal in three out of nine NHL patients at presentation and became abnormal during followup in one case. Abnormal distribution of $B$ cells in the blood is therefore found in only $33 \%$ of the patients with an orbital NHL at admittance. In one of the patients with a pseudolymphoma or chronic inflammation in the orbit was such a monoclonal B cell population found in the blood. These results suggest that no definite diagnosis can be made without a surgical intervention. In contrast to the recommendations advocating fine needle aspiration to obtain a biopsy of the tumour ${ }^{24}$ we found that open surgery was the safest procedure to avoid sampling errors. In addition lateral orbitotomy was preferable to anterior orbitotomy for deep orbital lesions in order to avoid damage to delicate orbital structures ending up with complications such as ptosis, diplopia, orbital haemorrhage, or blindness.

Part of this study was devoted to the use of immunohistochemistry in addition to light microscopical examination for a more refined diagnosis of lymphoid proliferations. Analysis of cell surface and cytoplasmic markers with the immunofluorescence technique on tissue obtained during surgery clearly benefited the routine histopathological diagnosis, because cells which were morphologically identical could be classified as of monoclonal or polyclonal origin. On two occasions the immunopathological diagnosis differed from the light microscopical observations. An explanation for such discrepancies may lie in the subdivision of biopsied tumour, in which case one diagnosis was made on tumour tissue, whereas the other diagnosis was made on tissue with inflammatory infiltrate often accompanying neoplasms. Only serial sectioning of the whole biopsy would allow a definite conclusion to be drawn. In these doubtful cases treatment was based on the diagnosis which classified the process as malignant.

Additional diagnostic examinations included lymphoid cell subpopulation determination on tumour cells teased from the biopsy specimen and electron microscopic investigation. Studying cells in suspension had the advantage that numerical counts of different lymphocyte subsets could be done. Knowles and Jacobiec ${ }^{25}{ }^{26}$ reported that the percentage of $T$ cells in a tumour cell suspension was indicative of malignancy if less than $20 \%$ of the cells were T cells, whereas a benign proliferation contained over $40 \% \mathrm{~T}$ cells. In the six cases where enough viable cells were teased from the tumour to perform a similar study the general trend of their investigation could be confirmed. Nevertheless there is a definite advantage in studying tissue sections" over cell suspensions, because the structure of the tissue is maintained. Many different areas of one tumour can be screened, and no contamination with peripheral blood lymphocytes occurs. Moreover sclerotic tissue from which it is difficult to tease cells can also be investigated immunologically.

Although our series is small (three NHLs and two pseudolymphomas) the electron microscopic investigation did not contribute greatly to the light microscopic and immunohistochemical diagnosis. Material fixed for electron microscopy should therefore be stored and only processed for investigation if a definite diagnosis cannot be reached by clinical, pathological, and immunological investigations alone.

Accurate and prompt diagnosis of the lymphoid proliferation in the orbit resulted in better adjusted treatment for each group of patients. So far the results of treatment (mean follow-up period 15 months, range three to 90) consisting of no treatment or postoperative prednisolone in the case of pseudolymphoma and local radiation therapy (4000 rads) in the case of NHL were favourable and resulted in the decrease of oedema, epiphora, proptosis, and improvement of motility. Careful follow-up of the pseudolymphoma patients and the patients with a chronic inflammatory process is mandatory in order to study whether a neoplastic disorder can arise locally from a reactive process. To date we have not observed such an evolvement in any of our patients.

This study therefore shows that it was not possible to obtain an accurate diagnosis of the space occupying orbital process by non-invasive means alone. But immunological and cytological investigation of bone marrow and peripheral blood, as part of the staging procedure, remain necessary to exclude generalised disease in the NHL patients. From this study we concluded that detailed ophthalmological examination appears to give a fairly accurate impression of the possible type of process one may encounter. Light microscopical examination should be supplemented when necessary with immunological examination of frozen tissue or tumour cells in suspension in order to discriminate NHL from pseudolymphomas. Good data, thorough integration of clinical symptoms, and light microscopical and immunohistochemical investigation have led to a clear discrimination between the three different kinds of lymphoid proliferations encountered in the orbit.

The authors wish to thank Mr J. Scholten, Mrs J. Thomassen-Heins, Mrs M. Rijken, Ms A. Iprenburg, and Ms H. Spiele for technical assistance. We are also grateful to $\mathrm{Dr} \mathrm{B}$. Verbeeten for granting us permission to reproduce the CT scans, and to Ms J. C. M. Beentjes and Mrs $\mathbf{J}$. Haages-Manck for assistance in preparing this manuscript. 


\section{References}

1 Knowles DM, Jakobiec FA. Ocular adnexal lymphoid ncoplasms. Hum Pathol 1982; 13: 148-62.

2 Tewfik NH, Platz CE, Corder P, Panther SK, Blodi FC. A clinicopathologic study of orbital and adnexal non-Hodgkin's lymphoma. Cancer 1979; 44: 1022-8.

3 Bleeker GM, Wagenaar SS, Peeters HJF, Hymans W, Oudshoorn HH, van Sloten EA. Orbital inflammatory pseudotumour. Mod Probl Ophthalmol 1975; 14: 393-7.

4 Peeters HJF, van Heerde P, Feltkamp-Vroom ThM. Pseudotumours, a clinical concept. Doc Ophthalmol 1982; 52: 387-91.

5 Bleeker GM, Feltkamp-Vroom ThM, van Heerde P. Immunological aspects of orbital diseases. In: Lessel S, van Dalen JTW, eds. Neuro-ophthalmology. Amsterdam: Excerpta Medica, 1981: 1: 262-81.

6 Knowles DM, Jakobiec FA. Orbital lymphoid neoplasm: clinical, pathologic and immunologic characteristics. In: Jakobiec FA ed. Ocular and adnexal tumours. Birmingham, Alabama: Aesculapius, 1978: 806-36.

7 Knowles DM, Jakobiec FA, Halper JP. Immunologic characterization of ocular adnexal lymphoid neoplasms Am J Ophthalmol 1979; 87: 603-19.

8 Kelly AG, Rosas-Uribe A, Kraus ST. Orbital lymphomas and pseudolymphomas. A clinicopathologic study of cleven cases. Am J Clin Pathol 1977; 68: 377-87.

9 Garner A, Rahi AHS, Wright JE. Lymphoproliferative disorders of the orbit: an immunological approach to diagnosis and pathogenesis. BrJ Ophthalmol 1983; 67: 561-9.

10 Koornneef L, Melief CJM, Peterse HL, Wilmink JM. Wegener's granulomatosis of the orbit. Diagnostic and therapeutic problems. Orbit 1983; 2: 1-11.

11 van Heerde P, Feltkamp CA, Feltkamp-Vroom ThM, Koudstaal J, van Unnink JAM. Non-Hodgkin's lymphoma. Immunohistochemical and electron microscopical findings in relation to light microscopy. Cancer 1980; 46: 2210-20.

12 Feltkamp CA, van Heerde P, Feltkamp-Vroom ThM, Koudstaal J. A malignant tumour arising from interdigitating cells; light microscopical, ultrastructural, immuno- and enzyme-histochemical characteristics. Virchows Arch (Pathol Anat) 1981; 393: 183-92.

13 van Rijn M, Geurts van Kessel AHM, Kroezen V, et al. Location of a gene controlling the expression of the human transferrin receptor in the region Q 12-Q ter of chromosome 3. Cytogenet Cell Genet in press.
14 Decary F, van Helden-Henningheim L, Engelfriet CP. Pitfalls in performing the indirect immunofluorescence test with anti-IgG on human peripheral blood lymphocytes. Amsterdam: thesis, 1977.

15 van der Reyden HJ, van der Gaag R, Pinkster J, et al. Chronic lymphocytic leukemia. Immunological markers and functional properties of the leukemic cells. Cancer 1982; 50: 2826-33.

16 Jondal M, Holm G, Wigzell H. Surface markers on human $T$ and B lymphocytes. I A large population of T lymphocytes forming non-immune rosettes with sheep red blood cells. J Exp Med 1972; 136: $207-15$.

17 van der Gaag R, Christiaans BJ, Rothova A, Baarsma GS, Dandrieu MR, Kijlstra A. Lymphocyte subpopulations in uveitis patients. In: Chandler JW, O'Connor GR, eds. Proceedings of the 3rd international symposium on immunology and immunopathology of the eye. New York: Masson, in press.

18 Lennert K, Stein H, Kaiserling E. Cytological and functional criteria for the classification of malignant lymphomata. $\mathrm{Br} J$ Cancer 1975; 31(suppl 11): 29-43.

19 Shindelman JE, Ortmeyer AE, Sussman HH. Demonstration of the transferrin receptor in human breast cancer tissue. Potential marker for identifying dividing cells. Int $J$ Cancer 1981; 27: 329-34.

20 Habeshaw JA, Lister TA, Stansfeld AG, Greaves MF. Correlation of transferrin receptor expression with histological class and outcome in non-Hodgkin lymphoma. Lancet 1983; i: 498-500.

21 Kaiserling E. Ultrastructure of non-Hodgkin's lymphomas. In: Kehlinger E ed. Malignant lymphomas other than Hodgkin's disease. Berlin, Heidelberg, New York: Springer, 1978: 471-528.

22 Heersink B, Rodrigues MR, Flanagan JC. Inflammatory pseudotumor of the orbit. Ann Ophthalmol 1977; 9: 17-29.

23 Haller Yeo J, Jakobiec FA, Abott GF, Trokel SL. Combined clinical and computed tomographic diagnosis of orbital lymphoid tumor. Am J Ophthalmol 1982; 94: 235-45.

24 Tarkkanen A, Koivuniemi A, Liesmaa M, Merenmies L. Fineneedle aspiration of biopsy in the diagnosis of orbital tumours. Albrecht von Graefes Arch Klin Ophthalmol 1982; 219: 165-70.

25 Knowles DM, Jakobiec FA. Quantitative determination of T cells in ocular lymphoid infiltrates. An indirect method for distinguishing between pseudolymphomas and malignant lymphomas. Arch Ophthalmol 1981; 99: 309-16.

26 Knowles DM, Jakobiec FA. Identification of T lymphocytes in ocular adnexal neoplasms by hybridoma monoclonal antibodies. Am J Ophthalmol 1983; 95: 233-42. 